\title{
HTLV-1 decreases Th2 type of immune response in patients with strongyloidiasis
}

\author{
AURÉLIA F.PORTO ${ }^{1}$, FRANKLIN A.NEVA ${ }^{2}$, HELITO BITTENCOURT ${ }^{3}$, WALDIR LISBOA ${ }^{4}$, ROBERT THOMPSON ${ }^{2}$, \\ LUíS ALCÂNTARA ${ }^{5}$ \& EDGAR M.CARVALHO ${ }^{1}$ \\ ${ }^{1}$ Serviço de Imunologia do Hospital Unversitário Prof. Edgard Santos, Universidade Federal da Bahia, Salvador, Bahia, Brazil, ${ }^{2}$ Laboratory of
Parasitic Diseases, National Institute of Allergy and Infectious Diseases, National Institute of Health, Bethesda, MD, USA, ${ }^{3}$ Instituto de
Gastroenterologia e Hepatologia, Salvador, Bahia, Brazil, ${ }^{4}$ Serviço de Transfusão de Sangue, Salvador, Bahia, Brazil and ${ }^{5}$ Laboratório Avançado
de Saúde Pública, Fundação Oswaldo Cruz, Salvador, Bahia, Brazil
}

\section{SUMMARY}

Eosinophils, immunoglobilin (Ig)E and cytokines have important roles in defence mechanisms against helminths. In this study, the influence of HTLV-1 infection, characterized by a Th1 type of immune response, was evaluated on the cytokine pattern and parasitic specific IgE response in patients with strongyloidiasis. Patients were divided into four groups: strongyloidiasis without HTLV-1 infection, strongyloidiasis with HTLV-1, HTLV-1 without strongyloidiasis and controls without either helminth infection or HTLV-1. The cytokine profile was determined in supernatants of mononuclear cells stimulated with Strongyloides stercoralis crude antigen and the parasite specific IgE was measured by ELISA. Patients coinfected with HTLV-1 had higher levels of interfron (IFN)- $\gamma$ and interleukin (IL)-10 $(P<0.05)$ and lower levels of IL-5 and IgE $(P<0.05)$ than patients with strongyloidiasis without HTLV-1. There was an inverse relationship between IFN- $\gamma$ and IL-5 $\left(P=0.01 ; r_{s}=-0.37\right)$ and between IFN- $\gamma$ and parasite specific $\operatorname{IgE}\left(P=0.01 ; \quad r_{s}=-0.39\right), \quad$ and a direct relationship between IFN- $\gamma$ and $I L-10 \quad(P=0 \cdot 04$; $\left.r_{s}=0 \cdot 35\right)$. These data show that coinfection with HTLV-1 decreases IL-5 and IgE responses in patients with strongyloidiasis consistent with a relative switch from $T h 2$ to Th1 response. Immunological responses such as these are important in the control of this helminthic infection.

Keywords HTLV-1, strongyloidiasis, IgE, S. stercoralis

Correspondence: Dr E.M.Carvalho, Hospital Universitário Prof. Edgard Santos, Laboratório de Imunologia $-5^{\circ}$ andar, Rua João das Botas s/n-Canela 40110-160, Salvador, Bahia, Brazil (e-mail: edgar@ ufba.br)

Received: 31 October 2000

Accepted for publication: 11 June 2001

\section{INTRODUCTION}

An association between strongyloidiasis and HTLV-1 infection has been documented in areas where these infections are endemic (1-4). While there is no agreement that HTLV-1 increases the prevalence of strongyloidiasis, there are strong data indicating that HTLV-1 has important clinical and immunological implications in this helminthic infection. For example, a high rate of therapeutic failure with thiabendazol and, consequently, chronic Strongyloides stercoralis infection has been documented in patients infected by HTLV-1 (5), and a severe form of disease with larval dissemination has been reported in patients coinfected with these two agents (6-9). Additionally, there is an inverse correlation between interferon (IFN)- $\gamma$ levels and total immunoglobulin (Ig)E in patients with HTLV-1 and strongyloidiasis (10).

Individuals infected with HTLV-1 have spontaneous $\mathrm{T}$ cell proliferation (11-13) and high levels of IFN- $\gamma$ (10), which are immunological functions asssociated with a Th1 type of immune response. The immune response in strongyloidiasis is not completely understood. Considering that helminthiases usually have a Th2 type immune response (14-18) and that levels of $\operatorname{IgE}$ in serum and interleukin (IL)-4 in cell supernatant fluids of patients with strongyloidiasis are elevated $(10,19,20)$, it appears that these patients have a predominantly $\mathrm{Th} 2$ type of immune response. This type of immune response may be important in controlling hyperinfection due to S. stercoralis, since both IgE and IL-4 participate in killing or expulsion of helminths from the host (21-24). Moreover, since IL-4 and IL-13 share receptor components (25), it is posible that there also is participation of IL-13 in the defence mechanisms against helminths. The aim of the present study was to determine the cytokine profile in patients with 
strongyloidiasis either coinfected or uninfected with HTLV1 and to evaluate whether the increased IFN- $\gamma$ production observed in patients coinfected with HTLV-1 and $S$. stercoralis may modulate the production of IL-5, IL-10, IL-13 and antigen specific $\operatorname{IgE}$ responses.

\section{MATERIALS AND METHODS}

\section{Patients}

Participants of the present study included HTLV-1 positive seroreactors from blood banks, and patients who lived in a rural endemic area for S. stercoralis near Salvador, state of Bahia, Brazil, with positive faecal examinations for $S$. stercoralis infection. A clinical history was taken and physical examination performed. The labouratory analysis included serology (IgE) for S. stercoralis, confirmation of HTLV-1 by Western blot and determination of cytokines (IFN- $\gamma$, IL-5, IL-10 and IL-13) in supernatant fluids of $S$. stercoralis antigen stimulated peripheral blood mononuclear cells (PBMC). Subjects were divided into four groups based on serology for HTLV-1 and S. stercoralis infection: group I comprised 20 individuals with negative serology for HTLV-1 and infected with S. stercoralis, group II comprised 20 patients coinfected with $S$. stercoralis and HTLV-1, group III comprised 20 individuals with positive serology for HTLV-1 and three negative stool examinations by the method of Baermann and group IV comprised 15 healthy subjects with negative serology and absence of helminths in the stool examination. The mean ages of patients in group I, group II group III and in group IV were $39 \pm 9$ years, $26 \pm 16$ years, $21 \pm 3$ and $20 \pm 4$, respectively, and the male/female ratio was $2 \cdot 3: 1,4: 1,3: 1$ and $1.4: 1$, respectively. All the patients were asymptomatic in relation to strongyloidiasis. The criterion for a diagnosis of strongyloidiasis was a positive faecal examination (Baermann technique). After blood collection, all patients were treated with cambendazol ( $5 \mathrm{mg} / \mathrm{kg}$ weight). Informed consent was obtained and the human experimentation guidelines of the Hospital Universitário Prof. Edgard Santos were followed in the conduct of this clinical research.

\section{Immunological studies}

\section{Antigen}

Antigen for serology was prepared from infective larval stage 3 (L3) of the parasite recovered from faecal specimens of infected monkeys, after being allowed to develop at $25^{\circ} \mathrm{C}$ in charcoal cultures. Larvae were separated from the charcoal by the Baermann procedure and washed repeatedly by centrifugation. They were then exposed to $0.25 \%$ chlorox (sodium hypoclhorite) for 3-5 min for surface sterilization followed by multiple cycles of centrifugation in RPMI medium (Gibco, Grand Island, NY, USA) containing $100 \mu \mathrm{g}$ per ml gentamicin. A soluble supernatant of sonicated larvae provided the somatic antigen used in the ELISA test.

\section{Serum specific-IgE assays}

S. stercoralis specific serum IgE was measured by ELISA on microtitre plates (Immulon 2; Dynatech Laboratories, Chantilly, VA, USA) as previously described (10). Sera were first depleted of IgG by treatment with Gamma Bind G Sepharose (Pharmacia Biotechnology, Uppsala, Sweden) before reaction with antigen overnight at $4^{\circ} \mathrm{C}$. Detection of antibody was performed with goat antihuman IgE conjugated to alkaline phosphatase (Sigma, St Louis, MO, USA); the substrate was $p$-nitrophenylphosphate (Sigma) and the results are expressed as international units (IU).

\section{Cytokine determination}

Cytokine levels (IFN- $\gamma$, IL-5, IL-10 and IL-13) in supernatants of mononuclear cells were measured by ELISA. Briefly, peripheral blood mononuclear cells were obtained by density gradient centrifugation using lymphocyte separation media (LSM; Organon Teknika Coorporation, Durham, NC, USA). After washing in saline, the cells were adjusted to $3 \times 10^{6} / \mathrm{ml}$ in RPMI 1640 (Gibco) supplemented with $10 \% \mathrm{AB}+$ sera containing $100 \mathrm{U}$ penicillin/G and $10 \mu \mathrm{g} / \mathrm{ml}$ of streptomycin. The cells were either unstimulated or stimulated with $S$. stercoralis antigen $(1 \mu \mathrm{g} / \mathrm{ml})$. All cultures were incubated at $37^{\circ} \mathrm{C}$ in $5 \%$ $\mathrm{CO}_{2}$ for $72 \mathrm{~h}$. Supernatant fluids were collected and stored at $-20^{\circ} \mathrm{C}$. IFN- $\gamma$ (Genzyme Corp., Cambridge, MA, USA), IL-5, IL-10 and IL-13 (PharMingen, San Diego, USA) levels were measured by ELISA sandwich technique (26) and the results were expressed in $\mathrm{pg} / \mathrm{ml}$ based on a standard curve generated using recombinant cytokines. Values represent the difference between the value of stimulated cultures minus the values of unstimulated cultures. Because we found that IFN- $\gamma$ levels in subjects infected with HTLV1 were similar in unstimulated or antigen stimulated cultures, for these groups of patients, the IFN- $\gamma$ data presented correspond to the values observed in unstimulated cultures.

\section{Serology for HTLV-1}

HTLV-1 serology was performed by ELISA test (Cambridge Biotech, Cambridge, MA, USA). Positive ELISA tests were confirmed by Western blot (HTLV Blot 2.4, Genelabs, Singapore). 


\section{Statistical analysis}

The correlations were analysed by Spearman correlation test. The Rank Sum Test was used to compare the means.

\section{RESULTS}

With the aim of determining the cytokine profile in patients with strongyloidiasis, coinfected or not with HTLV-1, the levels of IFN- $\gamma$, IL-5, IL-10 and IL-13 were determined in supernatants from $S$. stercoralis antigen stimulated lymphocyte cultures (Figure 1). The mean $\pm \mathrm{SD}$ of IFN- $\gamma$ levels in patients only infected with $S$. stercoralis was $20 \pm 46 \mathrm{pg} / \mathrm{ml}(0-192 \mathrm{pg} / \mathrm{ml})$ and the mean in supernatants of patients coinfected with $S$. stercoralis and HTLV1 was $919 \pm 944 \mathrm{pg} / \mathrm{ml} \quad(0-3470 \mathrm{pg} / \mathrm{ml}) \quad(P=0.01)$. Although there was a tendency for the IFN- $\gamma$ levels be higher in subjects only infected with HTLV-1 without strongyloidiasis $(2063 \pm 2499 \mathrm{pg} / \mathrm{ml}$ with variation of $15-$ $9675 \mathrm{pg} / \mathrm{ml}$ ) than in patients with HTLV-1 and strongyloidiasis $919 \pm 944 \mathrm{pg} / \mathrm{ml}(0-3470 \mathrm{pg} / \mathrm{ml})$, this diference was not statisticaly significant. The mean \pm SD of IL-5 levels in patients only infected with $S$. stercoralis was $727 \pm 554 \mathrm{pg} / \mathrm{ml}(0-1683 \mathrm{pg} / \mathrm{ml})$. This value was higher than that observed in patients coinfected with S. stercoralis and HTLV-1 $(173 \pm 168 \mathrm{pg} / \mathrm{ml}$ with variation of 0 $488 \mathrm{pg} / \mathrm{ml})(P<0.0001)$ and in subjects without HTLV-1 and without $S$. stercoralis infection $(2 \pm 2 \mathrm{pg} / \mathrm{ml})$. There was also a tendency for higher IL-13 levels in patients with strongyloidiasis without HTLV-1 $(220 \pm 361 \mathrm{pg} / \mathrm{ml})$ than

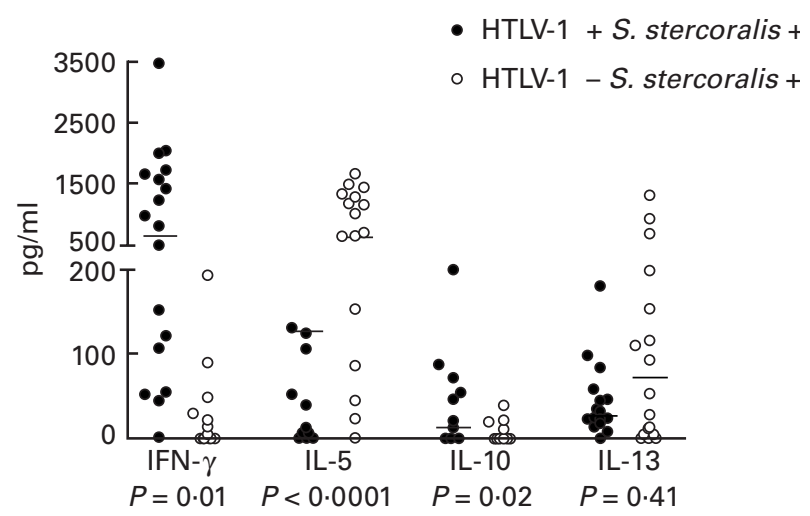

Figure 1 Cytokine profile in patients with strongyloidiasis coinfected or not with HTLV-1. Data for IFN- $\gamma$ and IL-5 were obtained from all 40 patients. IL-10 levels were documented in 17 blood donors only infected with $S$. stercoralis and in 15 blood donnors coinfected with $S$. stercoralis and HTLV-1. IL-13 levels were documented in 17 blood donnors only infected with $S$. stercoralis and in 20 blood donnors coinfected with S. stercoralis and HTLV-1. Values of IL-5, IL-10 and IL-13 represent the differences between the values of stimulated cultures minus the values of unstimulated cultures. The IFN- $\gamma$ data presented correspond to the value observed in unstimulated cultures. in patients coinfected with HTLV-1 $(43 \pm 45 \mathrm{pg} / \mathrm{ml})$ $(P=0.41)$. Although the levels of IL-5 and IL-13 in subjects only infected with $S$. stercoralis were higher than that observed in subjects coinfected with S. stercoralis and HTLV-1, there was a higher production of IL-10 in this last group. The mean \pm SD of IL-10 levels in first group was $5 \pm 11 \mathrm{pg} / \mathrm{ml}(0-37 \mathrm{pg} / \mathrm{ml})$ and in the group II was $35 \pm 53 \mathrm{pg} / \mathrm{ml}(0-532 \mathrm{pg} / \mathrm{ml})(P=0 \cdot 02)$. The level of IL-10 in patients only infected with HTLV-1 was $141 \pm 115 \mathrm{pg} / \mathrm{ml}(0-390 \mathrm{pg} / \mathrm{ml})$.

Parasite specific IgE levels in patients only infected with $S$. stercoralis were higher than in patients coinfected with HTLV-1 and S. stercoralis $(P=0.01)$. The mean \pm SD in the group I was $251 \pm 437 \mathrm{IU}$ and in the group II was $74 \pm 94$ IU.

The relationship between IFN- $\gamma$ production in supernatants of lymphocyte cultures and IL-5, IL-13 and serum specific IgE levels in 40 patients with strongyloidiasis, with or without HTLV-1 coinfection, is shown in Table 1. An inverse relationship between IFN- $\gamma$ and serum specific IgE $\left(P=0.01 ; r_{\mathrm{s}}=-0.39\right)$ and between IFN- $\gamma$ and IL-5 $\left(P=0.01 ; \quad r_{\mathrm{s}}=-0.37\right)$ was observed by Spearman analysis. When IL-5 production in supernatants of lymphocyte cultures was related to parasite specific IgE levels and to IL-13 in the same subjects, there was a direct relationship $\left(P=0.0001 ; \quad r_{\mathrm{s}}=0.57\right.$ and $P<0.0001$; $r_{\mathrm{s}}=0.75$, respectively). A direct relationship was also found between IFN- $\gamma$ and IL-10 levels in supernatants of lymphocyte cultures $\left(P=0.04 ; r_{\mathrm{s}}=0.35\right)$. However, IL10 levels were so low that it was difficult to interpret the results.

\section{DISCUSSION}

The present study shows that the cytokine profile in patients with strongyloidiasis is characterized by a predominance of IL-5 in relation to IFN- $\gamma$ and that high levels of antigen specific IgE antibodies against $S$. stercoralis are observed. Coinfection with HTLV-1 changes this immunological

Table 1 Correlations between IFN- $\gamma$, IL-5, IL-13 and specific IgE levels in patients infected with strongyloidiasis with or without HTLV1 coinfection

\begin{tabular}{lcc} 
Variables & $r$ & $P$ \\
\hline IFN- $\gamma$ and IgE & -0.39 & 0.01 \\
IFN- $\gamma$ and IL-5 & $-0 \cdot 37$ & 0.01 \\
IFN- $\gamma$ and IL-13 & -0.04 & 0.92 \\
IL-5 and IL-13 & $0 \cdot 75$ & $<0.0001$ \\
IL-5 and IgE & 0.57 & 0.0001 \\
\hline
\end{tabular}


response leading to a decrease of IL-5 and specific IgE antibodies against $S$. stercoralis.

The documentation that $\mathrm{CD}^{+}{ }^{+} \mathrm{T}$ cells are a heterogeneous population formed by Th1 and Th2 cells has contributed to our understanding of the modulation of the immune response and the pathogenesis of several diseases. CD4 Th1 cells secrete predominantly IL-2, IFN- $\gamma$ and TNF- $\alpha$, while Th 2 cells produce mainly IL- 4 , IL-5 and IL10 (27). A predominant Th1 type response suppresses Th2 cell differentiation (28) and Th2 cytokines such as IL-4 and IL-10 downregulate IFN- $\gamma$ Th1 functions (29). We have previously documented that HTLV-1 infection decreases IL-4 synthesis and total IgE levels in patients with strongyloidiasis (10). In this study, we extend these observations showing that coinfection with HTLV-1 leads to a decrease in levels of IL-5 and specific IgE antibodies against $S$. stercoralis.

IL-10 is a cytokine produced predominantly by macrophages, B cells and CD4 Th2 cells $(30,31)$. IL-10 has an important modulatory effect in the immune response, mainly suppressing macrophage function $(32,33)$, lymphocyte proliferation (34) and IFN- $\gamma$ synthesis (29). In comparison to IL-5 that was reduced in patients coinfected with HTLV-1 and S. stercoralis, there was a direct relationship between IFN- $\gamma$ and IL-10. Because high IFN$\gamma$ levels decrease Th2 cell function, it is likely that, in patients coinfected with HTLV-1 and S. stercoralis, the source of IL-10 was not CD4 Th2 cells. In these cases, it is possible that the increased levels of IL-10 observed in coinfected patients may be a host attempt to modulate the high levels of IFN- $\gamma$ production.

The majority of subjects infected with $S$. stercoralis have an asymptomatic or mild infection. When autoinfection occurs on a large scale, severe disease with parasitic dissemination is observed. Although the defence mechanism against $S$. stercoralis is not completely understood, based on histopathological findings in strongyloidiasis and on observations in other helminthic infections, cytokines, IgE, eosinophils and mast cells participate in helminthic expulsion and killing. IL-4 is the major cytokine that differentiates B cells to produce IgE, and both IL-4 and IL13 increase the intestinal fluid content, a phenomenon that may contribute to parasite rejection $(25,35)$. IL-5 is an important cytokine for differentiation, activation and proliferation of eosinophils $(36,37)$, which are cells that are involved in the killing of helminths (37). Mast cell degranulation mediated by IgE and parasite antigens is also involved in the expulsion of parasites (38). A reduction in numbers of eosinophils has been observed in patients with disseminated strongyloidiasis (39) and decreased total $\operatorname{IgE}$ antibody levels have been observed in patients with severe strongyloidiasis associated with HTLV-1 infection $(3,7,40)$.
Additional recent evidence for HTLV-1 as an important factor for disseminated strongyloidiasis has been reported from Peru (9). Our data showing decreases of IL-5, IL-13 and specific IgE in patients coinfected with HTLV-1 and $S$. stercoralis, suggest that a decrease in the Th2 type immune response mediated by high levels of IFN- $\gamma$ may be the immunological basis for the increased susceptibility of the coinfected patients to develop disseminated strongyloidiasis.

\section{ACKNOWLEDGEMENTS}

We thank Amélia de Jesus for help with statistical analysis. This work was supported by the Brazilian Research Council $(\mathrm{CNPq})$ and by NIH grant AI-30639. Dr Carvalho is senior investigator of CNPq. We thank Noilson Gonçalves who was responsible for the Immunoblotting tests and the UCI-Farma, São Paulo, SP who provided the cambendazol, secnidazol and mebendazol for treatment of the patients infected with $S$. stercoralis and other parasites.

\section{REFERENCES}

1 Nakada K, Kohakura M, Komoda $\mathrm{H}$ et al. High incidence of HTLV antibody in carriers of Strongyloides stercoralis. Lancet 1984; 1: 633.

2 Robinson RD, Lindo JF, Neva FA et al. Immunoepidemiologic studies of strongyloides stercolalis and human T lymphtropic virus type I infections in Jamaica. J Infect Dis 1994; 169: 692-696.

3 Hayashi J, Kishihara Y, Yoshimura E et al. Correlation between human $\mathrm{T}$ cell lymphotropic virus type-1 and strongyloides stercoralis infections and serum immunoglobulin E reponses in residents of Okinawa, Japan. Am J Trop Med Hygiene 1997; 56: $71-75$.

4 Plumelle Y, Gonin C, Edouard A et al. Effect of Strongyloides stercoralis infection and eosinophilia on age at onset and prognosis of adult T-cell leukemia. Am J Clin Pathol 1997; 107: 81-87.

5 Sato Y, Shiroma Y, Kiyuna S, Toma H, Kobayashi J. Reduced efficacy of chemotherapy might accumulate concurrent HTLV-I infection among strongyloidiasis patients in Okinawa, Japan. Trans Royal Soc Trop Med Hygiene 1994; 88: 59.

6 Phelps KR, Ginsberg SS, Cinningham AW, Tschachler E, Dosik H. Case report: adult T-cell leukemia/ lymphoma associated with recurrent strongyloides hyperinfection. Am J Med Sci 1991; 302: 224-228.

7 Newton RC, Limpuangthip P, Greenberg S, Gam A, Neva F. Strongyloides stercoralis hiperinfection in a carrier of HTLV-I virus with evidence of selective immunosuppression. Am J Med 1992; 92: 202-207.

8 Patey O, Gessain A, Breuil J et al. Seven years of recurrent severe strongyloidiasis in an HTLV-I-infected man who developed adult T-cell leukaemia. J Acq Immun Def Syndr Hum Retrovirol 1992; 6: 575-579.

9 Gotuzzo E, Terashima A, Alvarez H et al. Strongyloides stercoralis hyperinfection associated with human $\mathrm{T}$ cell lymphotropic virus type-1infection in Peru. Am J Trop Med Hygiene 1999; 60: 146149. 
10 Neva FA, Oliveira J, Gam AA et al. Interferon- $\gamma$ and interleukin-4 responses in relation to serum $\operatorname{IgE}$ levels in persons infected with human T lymphotropic virus type I and Strongyloides stercoralis. $J$ Infect Dis 1998; 178: 1856-1859.

11 Popovic M, Flomenberg N, Volkman DJ. Alteration of T-cell functions by infection with HTLV-I or HTLV-II. Science 1984; 226: 459-462.

12 Höllsberg P, Wucherpfenning W, Ausubel LJ, Calvo V, Bierer BE, Hafler DA. Characterization of HTLV-1 in vivo infected T cell clones. IL-2-Independent growth of non transformed T cells. $J$ Immunol 1992; 148: 3256-3263.

13 Arima N. Autonomous and interleukin-2-responsive growth of leukemic cells in adult T-cell leukemia (ATL): a review of the clinical significance and molecular basis of ATL cell growth. Leuk Lymph 1997; 26: 479-487.

14 Coffman RL, Seymour BWP, Haduk S, Jackson J, Rennik D. Antibody to interleukin 5 inhibits helminth-induced eosinophilia in mice. Science 1989; 245: 308-319.

15 King CL, Mahanty S, Kumaraswami V et al. Cytokine control of parasite-specific anergy in human lymphatic filariasis. Preferential induction of a regulatory $\mathrm{T}$ helper 2 lymphocyte subset. $J$ Clin Invest 1993; 92: 1667-1673.

16 Korenaga M, Hitoshi Y, Takatsu K, Tada I. Regulatory effect of anti-interleukin 5 monoclonal antibody of intestinal worm burden in a primary infection with S. venezuelensis. Int J Parasitol 1994; 24: 951-957.

17 Bancroft AJ, Else KJ, Sypek JP, Grencis RK. Interleukin 12 promotes a chronic intestinal helminth infection. Eur J Immunol 1997; 27: 866-877.

18 Rotman HL, Schnyder-Candrian S, Scott P, Nolan TJ, Schad GA, Abraham D. IL-12 eliminates the Th-2 dependent protective immune response of mice to larval Strongyloides stercoralis. Parasite Immunol 1997; 19: 29-39.

19 Mcrury J, Messias IT, Walzer PD. Specific IgE responses in human strongyloidiasis. Clin Exp Immunol 1986; 65: 631-638.

20 Rossi CL, Takahashi EEH, Partel CD. Total serum IgE and parasite-specific $\operatorname{IgG}$ and $\operatorname{IgA}$ antibodies in human strongyloidiasis. Revista Do Instituto Med Trop São Paulo 1993; 35: 361-365.

21 Ahmad A, Wang CH, Bell RG. A role for IgE in intestinal immunity. Expression of rapid expulsion of Trichinella spiralis in rats transfused with $\mathrm{IgE}$ and thoracic duct lymphocytes. J Immunol 1991; 146: 3563-3570.

22 Madden KB, Urban JF Jr, Ziltener HJ, Schrader JW, Finkelman FD, Katona IM. Antibodies to IL-3 and IL-4 suppress helminth induced mastocytosis. J Immunol 1991; 147: 1387-1391.

23 Urban JFJ, Maliszewski CR, Madden KB, Katona IM, Finkelman FD. IL-4 treatment can cure established gastrointestinal nematode infections in immunocompetent and immunodeficient mice. $J$ Immunol 1995; 154: 4675-4684.

24 Goldhill J, Morris SC, Maliszewski C et al. Interleukin-4 modulates cholinergic neural control of mouse small intestinal longitudinal muscle. Am J Physiol 1997; 272: G1135-G1140.
25 Barner M, Mohrs M, Brombacher F, Kopf M. Differences between IL-4R $\alpha$-deficient and IL-4-deficient mice reveal a role for IL-13 in the regulation of Th2 responses. Curr Biol 1998; 8: 669-672.

26 Russo DM, Turco SJ, Burns JM, Reed SG. Stimulation of human T lymphocyte by Leishmania. J Immunol 1992; 148: 202-207.

27 Romagnani S. Type $1 \mathrm{~T}$ helper and type $2 \mathrm{~T}$ helper cells: functions, regulation and role in protection and disease. Int J Clin Lab Res 1992; 21: 152-158.

28 Klimpel GR, Infante AJ, Patterson J, Hess CB. Virus-induced interferon alpha/beta (IFN-alpha/beta) production by $\mathrm{T}$ cells and by Th1 and Th2 helper $\mathrm{T}$ cell clones: a study of the immunoregulatory actions of IFN-gamma versus IFN-alpha/beta on functions of different T cells populations. Cell Immunol 1990; 128: $603-618$

29 Fiorentino DF, Bond MW, Mosmann TR. Two types of mouse helper T cells. IV. Th2 clones secrete a factor that inhibits cytokine production by Th1 clones. J Exp Med 1989; 170: 2081-2098.

30 Yssel H, de Wall Malefyt R, Roncarolo MG et al. Il-10 is produced by subsets of human $\mathrm{CD} 4+\mathrm{T}$ cell clones and peripheral blood $\mathrm{T}$ cells. J Immunol 1992; 149: 2378-2384.

31 Moore KW, O'Garra A, de Wall Malefyt R et al. Interleukin-10. Annu Rev Immunol 1993; 11: 165-190.

32 Fiorentino DF, Zlotnik F, Mosmann TR et al. IL-10 inhibits cytokine production by activated macrophages. J Immunol 1991; 147: 3815-3821.

33 Sher A, Fiorentino D, Gaspar P, Pearce E, Mosmann T. Production of IL-10 by CD4 + T lymphocytes correlates with down-regulation of Th1 cytokine synthesis in helminthic infection. J Immunol 1991; 147: 2713.

34 Taga K, Tosato G. IL-10 inhibit T cell proliferation and IL-2 production. J Immunol 1992; 148: 1143-1149.

35 Finkelman FD, Shea-Donohue T, Goldhill. J et al. Cytokine regulation of host defense against parasitic gastrointestinal nematodes: lessons from studies with rodent models. Аnпи Rev Immunol 1997; 15: 505-533.

36 Finkelman FD, Pearce EJ, Urban JF, Sher A. Regulation and biological function of helminth-induced cytokine responses. Immunol Today 1991; 12: A62-A66.

37 Hogarth PJ, Bianco AE. IL-5 dominates cytokine responses during expression of protective immunity to Onchocerca linealis microfilariae in mice. Parasite Immunol 1999; 21: 81-88.

38 Capron M, Rousseaux J, Mazingue C, Bazin H, Capron A. Rat mast cell-eosinophil interaction in antibody-dependent eosinophil cytotoxicity to Schistosoma mansoni schistosomula. J Immunol 1978; 121: 2518-2524.

39 Carvalho EM, Andrade TM, Andrade JA, Rocha H. Immunological features in different clinical forms of strongyloidiasis. Trans Royal Soc Trop Med Hygiene 1983; 77: 346-349.

40 Atkins NS, Lindo JF, Lee MG et al. Immunomodulatory effects of concurrent HTLV-I infection in strongyloidiasis. $J$ Acq Immun Defic Syndr Hum Retrovirol 1998; 18: 188-190. 